\title{
PENGENALAN JENIS TERIPANG EKONOMIS PENTING BAGI MASYARAKAT DESA SULI KABUPATEN MALUKU TENGAH
}

\author{
Gratia Dolores Manuputty), Maureen Mercy Pattinasarany2), \\ Gino Valentino Limmon ${ }^{3)}$ \\ ${ }^{1)}$ Ilmu Kelautan, FPIK Universitas Pattimura \\ ${ }^{2}$ Budidaya Perairan, FPIK Universitas Pattimura \\ ${ }^{3)}$ Pusat Kemaritiman dan Kelautan, Universitas Pattimura \\ Email: gd.manuputty@gmail.com
}

\begin{abstract}
ABSTRAK
Pemanfaatan teripang semakin meningkat seiring dengan meningkatnya permintaan akan komoditi ini karena harganya yang tinggi. Pada beberapa tempat di Maluku, pemanfaatan teripang juga cukup tinggi, dan teripang masih ditemukan cukup melimpah di alam. Sedangkan pada beberapa lokasi lain, teripang justru tidak terlalu dimanfaatkan, karena masih rendahnya pengetahuan masyarakat akan manfaat dan nilai ekonomi dari komoditi ini. Pemanfaatan teripang juga masih terbatas pada beberapa spesies yang telah umum dikenal memiliki nilai jual, misalnya teripang pasir (Holothuria scabra), teripang susu (H. fuscogilva), dan teripang ananas (Thelenota ananas). Padahal, jenis teripang yang memiliki nilai ekonomis masih cukup banyak, dan sumberdayanya tersedia di perairan Maluku. Untuk itu, diperlukan upaya untuk mengenalkan jenis-jenis teripang bernilai ekonomis penting yang ada di Maluku. Desa Suli memiliki substrat pantai yang sesuai dengan habitat hidup teripang, namun pemanfaatannya masih sangat jarang. Sehingga dirasakan penting untuk melakukan kegiatan pengenalan jenis teripang ekonomis penting di Suli. Berdasarkan hasil kegiatan, dijumpai bahwa masih banyak masyarakat yang tidak mengetahui bahwa ada banyak teripang yang memiliki nilai ekonomis penting. Selain itu, masih rendah tingkat pemanfaatan teripang maupun upaya untuk mengelolanya, misalkan budidaya dan pengolahan teripang. Setelah kegiatan ini, masyarakat semakin mengenal jenis-jenis teripang yang memiliki nilai ekonomi, harga jual dan pasarnya.
\end{abstract}

Keywords: Teripang, Pengenalan Jenis, Ekonomis Penting, Maluku, Suli

\section{ABSTRACT}

Sea cucumbers utilization is increasing along with the increasing of the demand due to their high prices. In some places in Maluku, the exploitation is quite high, and the commodities are relatively abundant in nature. However, in some other locations, sea cucumbers are not certainly utilized, as the result of the low level of public knowledge about their benefits and economic value. Sea cucumbers usage is still limited to several species that are commercially known yet, e.g. sandfish (Holothuria scabra), white teatfish (H. fuscogilva), and prickly redfish (Thelenota ananas). In fact, the commercial species of sea cucumbers are plenty, and the resources are available in Maluku waters. Hence, efforts are needed to introduce the commercial species of sea cucumbers in Maluku. Suli, a coastal village, has shore substrates that are suitable for habitats of sea cucumber, yet the resources are rarely utilized. Thus, the introduction of commercial sea cucumbers species is imperative to conduct. The result of the activity showed that the community has not acquainted yet with various species of commercial sea cucumbers. In addition, either the exploitation or the management, for instance the cultivation and processing, were moderate. Following the activity, the community's knowledge in relation to commercial species of sea cucumbers, the economic value and markets, were developed.

Keywords: Sea Cucumbers, Species Introduction, Commercial, Maluku, Suli 


\section{PENDAHULUAN}

Teripang dikenal dengan nama timun laut, Suala, Sea cucumber, beche de-mer atau dalam nama pasar international teat fish. Dan hasil penelitian teripang mempunyai kandungan gizi yang tinggi, yaitu kandungan protein $82 \%$, lemak 1,7 \% kadar air 8,9\%, kadar abu 8,6\% dan karbohidrat 4,8\%. Teripang dipasarkan dalam bentuk produk jadi seperti teripang kering (beche de-mer), usus asin (konowata), gonad kering (konoko), otot kering, teripang kaleng, kerupuk teripang. Pasaran utama dan teripang tersebut antara lain beberapa negara Eropa, Jepang, Singapura, malaysia, dan Amerika.

Massin (1999) menyatakan bahwa teripang dapat ditemukan pada perairan di berbagai tempat di dunia mulai dari perairan pasang surut yang dangkal hingga perairan yang lebih dalam, antara lain seperti Laut Merah, Somalia, Kenya, Madagscar, Mauritius, Srilangka, Maldive Islands, India, Myanmar, Malaysia, Papua New Guinea, Australia, Filipina, Vietnam, China, Japan, New Caledonia, Fiji, Christmas islands, Tuvalu, Vanuatu, Guam, dll. Penyebaran teripang di Indonesia sangat luas. Beberapa daerah penyebarannya antara lain Sumatera, Jawa, Sumbawa, Sulawesi, Selayar, Kepulauan Tukang Besi, Pulau Ambon, Kepulauan Lucipara, Laut Banda, Kepulauan Sula, Kepulauan Kei, Papua, dll.

James (1994), Massin (1999) dan Agudo (2006) mengamati bahwa teripang menyukai hidup pada perairan dangkal, biasanya kurang dari $20 \mathrm{~m}$, pada daerah-daerah yang terlindungi, dengan kandungan nutrien yang tinggi, dan dapat hidup beradaptasi pada berbagai habitat yang meliputi habitat berlumpur, berpasir, berbatu, koral, padang lamun dan daerah pertumbuhan algae.

Teripang dapat ditemukan pada perairan pantai di berbagai tempat di Indonesia termasuk di Maluku dengan berbagai nama lokal seperti teripang pasir, teripang gosok, maupun teripang putih. Di Maluku, teripang ditemukan melimpah pada pesisir pantai dengan kedalaman kurang dari $20 \mathrm{~m}$ hingga pada perairan yang cukup dalam, pada daerah-daerah yang terlindungi, dengan kandungan nutrien yang tinggi, dan dapat hidup beradaptasi pada berbagai habitat yang meliputi habitat berlumpur, berpasir, berbatu, koral, padang lamun dan daerah pertumbuhan algae.

Pemanfaatan teripang dari waktu ke waktu semakin meningkat, seiring dengan meningkatnya permintaan akan komoditi ini. Populasi teripang di alam dilaporkan telah mengalami tekanan eksploitasi di berbagai tempat. Hal ini ditandai dengan berkurangnya hasil tangkapan di alam maupun ukuran maksimum yang semakin mengecil seperti yang telah dilaporkan di berbagai tempat di dunia termasuk di Indonesia (Lawrence et al., 2004; Tuwo, 2004; Uthicke, 2004; Al-Rashdi and Claereboudt, 2010).

Pada beberapa tempat di Maluku, pemanfaatan teripang juga cukup tinggi, karena nilai jual teripang sangat tinggi dan mudah diperoleh, serta cukup melimpah di alam. Sedangkan pada beberapa lokasi lain, teripang justru tidak terlalu dimanfaatkan, karena masih rendahnya pengetahuan masyarakat akan manfaat dan nilai ekonomi dari komoditi ini. Namun demikian, pemanfaatan teripang masih terbatas pada beberapa spesies yang telah umum dikenal memiliki nilai jual, misalnya teripang pasir (Holothuria scabra), teripang susu (H. fuscogilva), dan teripang ananas (Thelenota ananas). Padahal, jenis teripang yang memiliki nilai ekonomis masih cukup banyak, dan sumberdayanya tersedia di perairan Maluku.

Kendala yang ditemui adalah masih rendahnya pengetahuan masyarakat mengenai jenis-jenis teripang ekonomis penting lainnya, serta pasar. Kendala lainnya adalah tekanan lingkungan yang menyebabkan keberadaan teripang semakin berkurang atau ukurannya yang kecil. Kendala ini juga dialami pada masyarakat Desa Suli, karena pola mata pencaharian masih berpusat di darat, dan laut hanya dijadikan sebagai lokasi untuk 
wisata dan kegiatan bameti (mencari kekerangan dan siput laut ketika air air surut) secara tradisional. Desa Suli memiliki substrat pantai yang sesuai dengan habitat hidup teripang (berlumpur, berpasir, berbatu, koral, padang lamun dan daerah pertumbuhan algae) (Manuputty dan Noya, 2017), namun pemanfaatan perairan pesisir Suli cukup terbatas dan hanya dimanfaatkan oleh beberapa orang saja. Perairan Suli memiliki kekayaan sumberdaya beberapa jenis teripang ekonomis penting, walaupun dengan potensi yang rendah (Pattinasarany dan Manuputty, 2017; Manuputty dan Pattinasarany, 2017; Manuputty, dkk., 2019).

Meskipun ditemukan dengan potensi yang rendah, namun tingginya jumlah spesies ekonomis penting yang ditemukan di perairan Suli berdasarkan hasil penelitian yang ada dapat memberi peluang pengelolaan di kemudian hari agar sumberdaya teripang dapat dimanfaatkan secara berkelanjutan. Misalnya, melalui kegiatan konservasi maupun budidaya berbasis alam (natural based cultivation) dengan tujuan memelihara habitat alami teripang. Berdasarkan hali ini, maka dirasakan penting untuk melakukan kegiatan pengenalan jenis teripang ekonomis penting yang ada di perairan Suli. Untuk itu, tujuan dilakukannya kegiatan PkM ini adalah untuk mengenalkan kepada masyarakat melalui kegiatan pengenalan mengenai jenis-jenis teripang bernilai ekonomis yang ada di perairan Suli.

\section{TINJAUAN PUSTAKA}

Klasifikasi teripang yang hidup di perairan tropis dapat dibagi ke dalam beberapa suku dan genus. Clark \& Rowe (1971) dan Cannon \& Silver (1987) mengemukakan klasifikasi teripang yang hidup di perairan tropis sebagai berikut:

Filum: Echinodermata

Kelas: Holothuridea

Ordo: Aspidochirotida

Famili: Holothuriidae

Genus: Actinopyga; Bohadschia; Holothuria

Famili: Stichopodidae

Genus: Thelenota; Stichopus

Ordo: Apodida

Famili: Synatidae

Genus: Opheodesoma

Secara morfologis, teripang umumnya berwarna hitam atau coklat tetapi ada juga jenis yang mempunyai warna terang seperti merah muda, violet, kehijauan, ataupun kuning. Tubuh teripang umumnya lunak dan licin, berotot (tebal atau tipis), permukaan kulitnya bervariasi halus ataupun bintik-bintik (Purwati dan Wirawati, 2009; Purcell, et al., 2012).

Permukaan tubuh teripang pada umumnya kasar karena adanya spikula pada dinding kulitnya. Spikula merupakan endoskeleton yang telah tereduksi menjadi ukuran mikroskopis dan tertanam dalam lapisan dermis dinding tubuh teripang. Bentuk spikula bermacam-macam dan khas untuk masing-masing jenis. Oleh karena itu, spikula dapat menjadi ciri teripang pada tingkat genus dan spesies.

Setidaknya terdapat kurang lebih 58 jenis teripang yang dieksploitasi di seluruh dunia (Purcell, 2012). Namun tidak semua jenis tersebut ada di Indonesia. Pada kegiatan penyuluhan ini, diperkenalkan 23 jenis yang umum dieksploitasi di Indonesia, dan 11 jenis di antaranya terdapat di perairan padang lamun Suli (menurut hasil kajian Pattinasarany dan Manuputty, 2017). Jenis yang diperkenalkan kepada masyarakat tidak terbatas pada yang ditemukan di perairan padang lamun saja. 


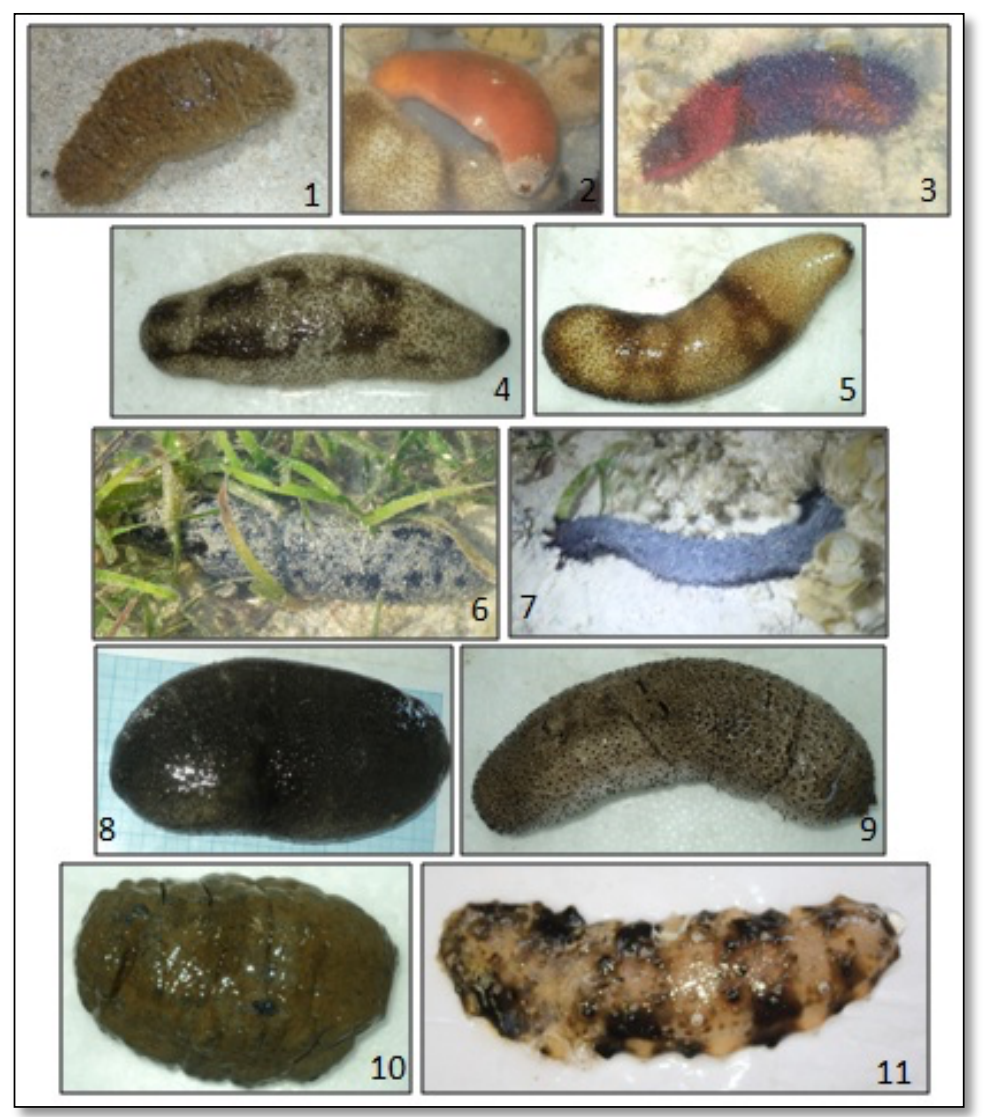

Gambar 1. Jenis Teripang Ekonomis Penting yang Ditemukan di Ekosistem Padang Lamun Perairan Suli

Gambar 1 menunjukkan jenis-jenis (spesies) teripang bernilai ekonomis penting yang dapat ditemukan di perairan Suli. Berdasarkan hasil penelitian Manuputty dan Pattinasarany (2017), setidaknya ditemukan 14 spesies teripang pada padang lamun. Dari 14 jenis teripang yang ditemukan di ekosistem padang lamun perairan Suli, terdapat 11 jenis yang memiliki nilai ekonomis penting dan telah diperdagangkan secara internasional. Ke-11 jenis tersebut antara lain: Actinopyga echinites (1), A. lecanora (2), A. miliaris (3), Bohadschia marmorata (4), B. vitiensis (5), Holothuria atra (6), $H$. coluber (7), H. lessoni (8), H. scabra (9), Stichopus chloronotus (10), dan S. horrens (10).

\section{METODE PELAKSANAAN}

\section{Tahap Pelaksanaan}

Kegiatan pengabdian kepada masyarakat mengenai pengenalan spesies teripang ekonomis penting dilakukan pada bulan Juni 2018, bertempat di Balai Desa Suli. Peserta yang mengikuti kegiatan ini berjumlah 20 orang, dimana yang menjadi sasaran adalah pemuda desa yang berusia produktif. Peserta merupakan kelompok pemuda keagamaan yang berusia produktif namun belum memiliki pekerjaan, sehingga hal ini menjadi kebutuhan sebagai salah satu bentuk peningkatan pengetahuan pemuda desa mengenai potensi wilayahnya. Inisiatif dibangun juga didasarkan pada peluang pemanfaatan dana desa yang dapat menunjang penyediaan sarana bagi aktivitas kepemudaan yang bersifat kreatif dan produktif.

Metode/pendekatan yang dilakukan adalah dalam bentuk penyuluhan menggunakan media visual, sehingga dapat menampilkan gambar-gambar yang menarik 
dan faktual berdasarkan hasil penelitan, agar masyarakat dapat mengenal dengan baik melalui tampilan visual yang tersedia. Dalam kegiatan ini, dilakukan proses diskusi untuk membuka wawasan dan menunjang penyerapan informasi yang diberikan, termasuk diskusi pengalaman pemuda selama melakukan kegiatan pemanfaatan pesisir bagi kehidupan sehari-hari. Untuk menunjang kegiatan ini, alat dan bahan yang dibutuhkan antara lain hasil penelitian terkait dan materi presentasi, media presentasi serta media dokumentasi.

\section{Evaluasi Keberhasilan}

Evaluasi keberhasilan dilakukan dengan mengkuantifikasi dan mempresentasikan pengetahuan masyarakat sebelum dan sesudah kegiatan. Evaluasi dilakukan dengan menggunakan kuisioner yang diisi langsung oleh peserta pada saat awal dan akhir kegiatan. Evaluasi yang dilakukan mencakup pengetahuan masayarakat tentang sumberdaya teripang, jenis (spesies) dan nilai jualnya.

\section{HASIL DAN PEMBAHASAN}

Kegiatan pengabdian kepada masyarakat ini diinisiasi berdasarkan hasil penelitian penulis yang menemukan bahwa perairan Suli, secara khusus pada ekosistem lamun, memiliki sumberdaya teripang yang tinggi. Hal ini dikomunikasikan dengan beberapa pemuda desa yang aktif terlibat di dalam kegiatan desa maupun keagamaan, dan ditemukan bahwa salah satu tujuan tenaga pemuda produktif di desa adalah dapat memanfaatkan potensi desa untuk kemajuan masyarakat bersama, termasuk lingkungan pesisir yang menyediakan jasa dari sisi ekonomi maupun ekologinya. Selain itu, dilihat bahwa pemanfaatan wilayah pesisir masih terbatas pada beberapa sumberdaya dari jenis kekerangan dan gastropoda (siput laut). Dan berdasarkan hasil diskusi, ditemukan bahwa hasil penelitian ini merupakan informasi baru yang dapat melengkapi pengetahuan masyarakat mengenai potensi perairan laut yang dimiliki desa.
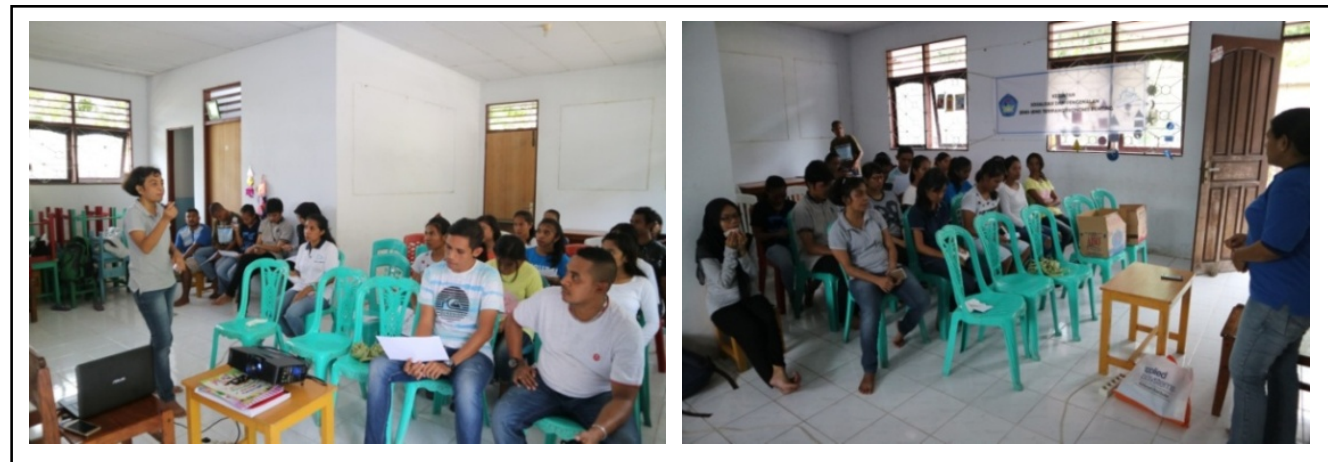

Gambar 2. Kegiatan Penyuluhan Pengenalan Jenis Teripang Bernilai Ekonomis Penting

Kegiatan pengenalan jenis teripang bernilai ekonomis penting dimaksudkan untuk mengenalkan kepada masyarakat jenis teripang yang memiliki nilai ekonomis penting (Gambar 2). Kegiatan pengenalan jenis teripang di perairan pantai Suli ini sekaligus merupakan bentuk diseminasi hasil penelitian dari Manuputty dan Pattinasarany (2017) kepada masyarakat Desa Suli, sehingga selain jenis yang diperkenalkan kepada masyarakat, juga diinformasikan mengenai nilai potensi masing-masing jenis yang ditemukan, agar masyarakat dapat memahami kondisi teripang pada perairan tersebut.

Hasil evaluasi terhadap tingkat keberhasilan kegiatan ini dilakukan dengan mengukur pengetahuan masyarakat mengenai sumberdaya teripang dan nilai 
ekonominya. Hasil menunjukkan terjadi peningkatan pengetahuan setelah dilakukan kegiatan pengenalan jenis teripang ekonomis penting, seperti tersaji pada Gambar 3. Hasil evaluasi menunjukkan adanya peningkatan pengetahuan terhadap adanya sumberdaya teripang di perairan Suli (45\% menjadi 100\%), pengetahuan mengenai jenis-jenis teripang ekonomis penting di pantai Suli (30\% menjadi $100 \%)$, dan pengetahuan mengenai nilai jual teripang (20\% menjadi $100 \%)$.

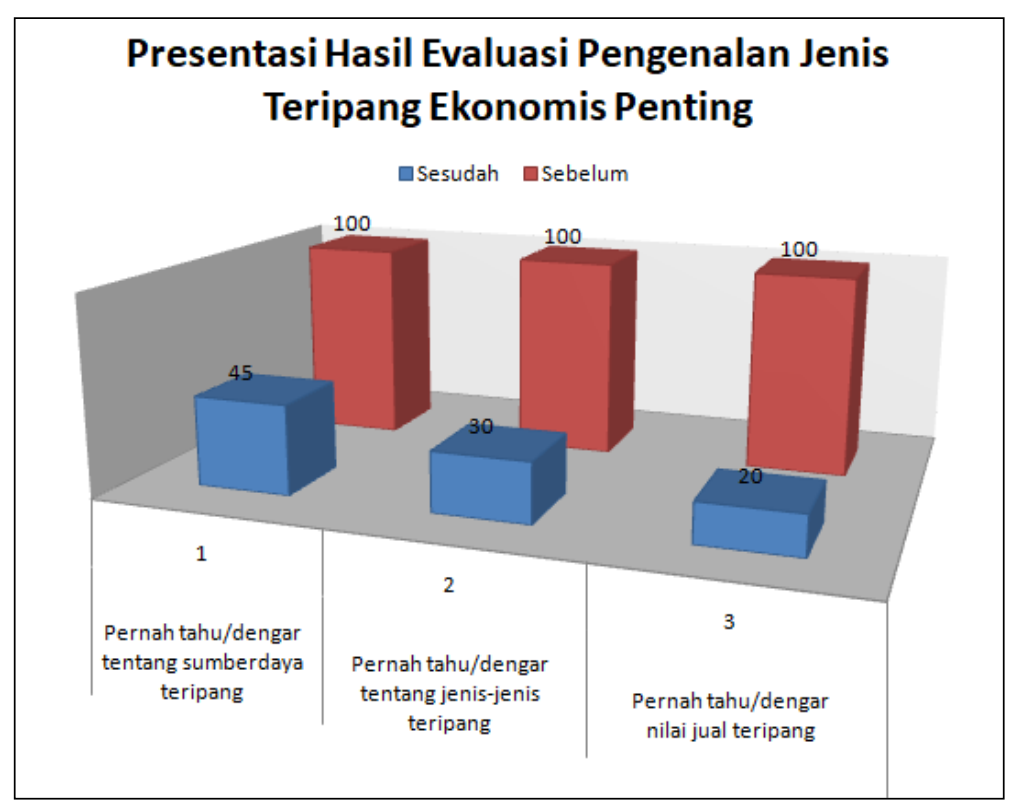

Gambar 3. Presentasi Hasil Evaluasi Pengenalan Jenis Teripang Ekonomis Penting

Melalui kegiatan ini, maka masyarakat direkomendasikan untuk dapat menjaga kelestarian teripang dengan cara memperhatikan lingkungan pantai, melakukan kegiatan bameti dan wisata pantai dengan memperhatikan kondisi ekosistemnya, dan secara khusus dapat mengkonservasi teripang dan habitatnya walaupun berbasis komunitas.

\section{KESIMPULAN}

Setelah melakukan kegiatan penyuluhan ini, masyarakat semakin memahami dan mengenal berbagai jenis teripang yang berada di perairan pantai Suli khususnya yang memiliki nilai ekonomi, mengetahui potensi teripang yang dimiliki, serta memahami langkah yang harus diambil untuk mengelola sumberdaya yang tersedia. Untuk itu diperlukan sinkronisasi antara pemerintah desa dengan pemuda gereja (sebagai sasaran dari kegiatan ini) agar dapat mengembangkan potensi yang tersedia dengan berkelanjutan.

\section{DAFTAR PUSTAKA}

[1]. Agudo, N. 2006. Sandfish Hatchery techniques. Australian Centre for International Agricultural Research (ACIAR), the Secretariat of the Pacific Community (SPC) and the WorldFish Center.

[2]. Al-Rashdi, K. M. And M. R. Claereboudt. 2010. Evidence of rapid Overfishig of Sea Cucumbers in the Sultanate of Oman. SPC Beche-de-mer Information Bulletin 30:10-13. 
[3]. Cannon, L. R. G. and H. Silver. 1987. Sea Cucumber of Northern Australia. Queensland Museum, South Brisbane, pp. 60.

[4]. Clark, A. M. and F. W. E. Rowe. 1971. Monograph of Shallow-water Indo-West Pacific Echinoderms. Trustees of the British Museum (p. 171-210).

[5]. James, D. B. 1994. Ecology of Commercially Important Holothurians of India. Bulletin Central Marine Fisheris Research Institution 46: 37-38.

[6]. Lawrence, J. 1987. A functional biology of echinoderms. The Johns Hopkins University Press. Baltimore. 340 pp.

[7]. Louhenapessy, D. G. dan J. M. F. Sahetapy. 2017. Aplikasi Sistem Informasi Geografi (SIG) untuk Analisis Kesesuaian Lahan Budidaya Teripang Pasir Holothuria scabra dengan Metode Pen Culture di Perairan Pesisir Negeri Suli Kecamatan Salahutu. LPPM Universitas Pattimura: Penelitian Dosen Pemula 2017.

[8]. Manuputty, G. D. dan M. M. Pattinasarany. 2017. Keanekaragaman Jenis dan Kelimpahan Sumberdaya Teripang di Ekosistem Padang Lamun Perairan Desa Suli. LPPM Universitas Pattimura: Penelitian Dosen Pemula 2017.

[9]. Manuputty, G. D., dan Y. A. Noya. 2017. Distribusi jenis teripang berdasarkan tipe substrat pada lokasi ekosistem padang lamun di Perairan Suli. Fakultas Perikanan dan Ilmu Kelautan, Universitas Pattimura. Penelitian Dosen Muda 2017.

[10]. Manuputty, G. D., M. M. Pattinasarany, G. V. Limmon, and A. Luturmas. 2019. Diversity and abundance of sea cucumber (Holothuroidea) in seagrass ecosystem at Suli Village, Maluku, Indonesia. 2019 IOP Conf. Ser.: Earth Environ. Sci. 339 012032

[11]. Massin, C. 1999. Reef-dwelling Holothuroidea (Echinodermata) of the Spermonde Archipelago (South-West Sulawesi, Indonesia). Zool. Verh. Leiden, 329:1-144.

[12]. Pattinasarany, M. M. dan G. D. Manuputty. 2017. Potensi Jenis Teripang Bernilai Ekonomis Penting di Ekosistem Padang Lamun Perairan Desa Suli Maluku Tengah. Disampaikan dalam Seminar Nasional Inovasi IPTEK Perikanan dan Kelautan (IIPK) ke-1, SwissBell Hotel, Ambon, 17 November 2017.

[13]. Purcell, S. W. 2014. Processing sea cucumbers into beche-de-mer: A manual for Pacific Island fishers. Southern Cross University and the Secretariat of the Pacific Community. pp 52.

[14]. Purcell, S.W., Y. Samyn, \& C. Conand. 2012. Commercially important sea cucumbers of the world. FAO Species Catalogue for Fishery Purposes. No. 6. Rome, FAO. 2012. 150 pp.

[15]. Purwati, P. dan I. Wirawati. 2009. Holothuriidae (Echinodermata, Holothuroidea, Apidochirotida) Perairan Dangkal Lombok Bagian I. Genus Holothuria. Jurnal Oseanologi, 10 Juli 2013.

[16]. Tuwo, A. 2004. Status of Sea Cucumber fisheries and Farming in Indonesia. In: Lovatelli, A., C. Conand, S. W. Purcell, S. Uthicke, J.-F. Hammel, and A. Mercier. Eds. Advances in sea cucumber aquaculture and management. FAO Fisheries Technical Paper 463. FAO, Rome. pp.49.

[17]. Uthicke, S. 2004. Overfishing of Holothurians; lessons from the Great Barrier Reef. In: Lovatelli, A., C. Conand, S. W. Purcell, S. Uthicke, J.-F. Hammel, and A. Mercier. Eds. Advances in sea cucumber aquaculture and management. FAO Fisheries Technical Paper 463. FAO, Rome. pp.49. 